\title{
Four challenges in the field of alternative, radical and citizens' media research
}

\section{Clemencia Rodríguez}

University of Oklahoma, USA

\section{Benjamin Ferron}

Centre de Recherches sur l'Action Politique en Europe SciencesPo Rennes, France

\section{Kristin Shamas}

Oklahoma City University, USA

\begin{abstract}
In January 1994 the Zapatista movement in southern Mexico inaugurated a new era of media use for dissent. Since that time, an array of dissenting collectives and individuals have appropriated media technologies in order to make their voices heard or to articulate alternative identities. From Zapatista media to the Arab Spring, social movements throughout the world are taking over, hybridizing, recycling, and adapting media technologies. This new era poses a new set of challenges for academics and researchers in the field of Communication for Social Change (CFSC). Based on examples from Mexico, Lebanon, and Colombia, this article highlights and discusses four such research challenges: accounting for historical context; acknowledging the complexity of communication processes; anchoring analysis in a political economy of information and communication technologies; and positioning new research in relation to existing knowledge and literature within the field of communication and social change.
\end{abstract}

\section{Keywords}

alternative media, Colombia, community media, Egypt, Israel-Palestine, Lebanon, Mexico, social media, social movements, social networks

\section{Corresponding author:}

Clemencia Rodríguez, Department of Communication, University of Oklahoma, Norman, OK 73019-0390, USA.

Email: clemencia@ou.edu 
Not too long ago mainstream media and social movements' media occupied different spheres, and rarely crossed paths. Corporate broadcasting and print existed in a universe of advertisers, target audiences, and a continuous commodification of leisure and information. In a separate sphere, social movements and media activists appropriated media technologies, divorced them from their corporate originators, and re-invented technology's uses in ways not intended by the designers. In the early 20th century, for example, print technologies were appropriated by anarchist movements in the United States, and by revolutionary groups in Mexico and Russia. By 1920 Bolivian tin miners were using radio technologies to mobilize their unions in their struggle for social justice against corporate and state oppressive forces (Downing, 2010). Similarly, during the 1968 revolts, workers and students' movements benefited from technological progress and lower prices in the systems of reprography to publish their own newspapers, as shown with the 'prensa marginal' in Mexico (Trejo, 1980), the 'parallel press' in France (Chadaigne, 2002), or the underground press in the United States (Lewes, 2000). Social movements and media activists learned to use media technologies to mobilize, express dissent, empower marginalized voices, or propose economic, political, and cultural alternatives.

Assuming that militant and alternative uses of media technologies are at least as important as mainstream media, communication scholars began documenting and theorizing instances in which marginal communities, social movements, or grassroots collectives use media technologies on their own terms (Kidd and Rodríguez, 2009). As early as the 1980s, communication scholars studied pirate radio in Europe (Drijvers, 1992; Hagerstrand, 1986; Jankowski et al., 1992; Lewis, 1984); 'medios populares' in Latin America (Fox and Schmucler, 1982; Huesca, 1996; Reyes Matta, 1983; Roncagliolo, 1991; Simpson Grinberg, 1981); guerrilla video and television in the United States and Canada (Boddy, 1990; Boyle, 1997; Downing, 1991; Halleck 2001; Thede and Ambrosi, 1991); traditional forms of communication for dissent and alternative media in Africa (Chipembere Lwanda, 2011; Nyamnjoh, 2006; OduroFrimpong, 2011; Spitulnik, 2003; Ugboajah, 2006); and indigenous media (Michaels, 1994; Roth and Valaskakis, 1989). Many different terms are used to label media technologies appropriated and used by social movements, citizens' groups and grassroots collectives, including: alternative media, social movements media, participatory media, community media, radical media, grassroots media, autonomous media, the French term 'médias libres', the Spanish term 'medios populares', and citizens' media (Rodríguez, 2001). ${ }^{1}$ Each term emphasizes different elements of autonomous media use and connects with specific theoretical frameworks, thus revealing the complex nature of media appropriation processes. While some researchers continued to produce isolated local or national monographs, others have progressively integrated this area of research into an international field that was first labeled Communication and Development (or Development Communication), better known today as Communication for Social Change (CfSC). Development Communication was originally founded on modernization theory and the use of media in Third World development. During the 1970s, a critical stand against modernization galvanized a conscious rupture with Development Communication, and the emerging critical approaches are loosely unified as CfSC. Community/alternative/citizens' media uses for mobilization and 
empowerment constitutes one of these critical approaches (Gumucio Dagron and Tufte 2006b; Rodríguez and Murphy, 1997; Waisbord, 2001).

With the recent emergence of so-called 'new information and communication technologies' and online platforms, alternative uses of media technologies are not clearly divorced from their corporate originators. Today, social justice and social movements' uses of platforms such as Facebook, Twitter, and YouTube remain within the corporate frameworks that underpin these platforms, a shift that helps explain why these uses of technology for social change have become such a magnet for mainstream media attention. This newly found excitement around social movements' uses of information and communication technologies (ICTs) has spilled over into academic research, creating a massive wave of studies on social media and social unrest, dissent, immigration, and human rights (Ali, 2011; Bennett and Segerberg, 2011; Christensen, 2011; Cottle and Lester, 2011; Harlow, 2012; Juris, 2012). For those of us doing research in the field of $\mathrm{CfSC}$, this trendy new line of research presents opportunities and challenges. On the one hand, the appropriation of media technologies by communities has rarely occupied such a central place in academia. On the other hand, this centrality brings its own risks. This article examines how the new era of Web 2.0 technologies used by activists and social movements presents a series of research challenges in the area of CfSC. Questioning the excitement around the availability and effectiveness of Web 2.0 platforms, we underscore the risks of neglecting historical context; we urge researchers to take into account the political economy frameworks of ICTs; we stress the need to overcome narrow definitions of communication; and, finally, we emphasize the urgency of grounding research on social movements and ICTs in the field of CfSC in order to avoid 're-inventing the wheel'.

\section{Risk one: neglecting historical context}

Recent corporate journalism and media in general are full of stories about communities using ICTs for dissent and social change. Popular sound bites such as 'the cell phone revolution' or 'the Twitter revolution' proliferate, even in the most traditional media sources. For example, in an often-cited op-ed article, Roger Cohen (2011) goes so far as to say that the 2011 Tunisian uprising was 'perhaps the world's first revolution without a leader. Or rather, its leader was far away: Mark Zuckerberg, the founder of Facebook'. After the 2009 Iranian student demonstrations became known as 'the Twitter revolution,' Mark Pfeifle (2009), a former national security adviser, called for Twitter to be nominated for the Nobel Peace Prize. This excitement around Web 2.0 platforms spills over into academic research. Whereas it was previously obscure and marginal, research on social movement media now comprises a bloated bibliography of trendy research topics such as ICTs and the Arab Spring, Occupy, or 'Indignados'. For instance, regarding the Arab Spring alone, a spate of articles across a variety of disciplines has sought to address the role of 'new media' (Axford, 2011; Gladwell, 2010; Howard and Hussain, 2011; Khondker, 2011; Zhuo et al., 2011).

Many of these studies, with their focus on the 'newness' of ICTs, reduce the richly contextual human relations that surround media use into a flat and unrevealing technological determinism. Semantically powerful soundbites such as 'the cell phone 
revolution' or 'the Twitter revolution' actually erase historical contexts and the passion(s) of politics, as technology becomes equated with political action. Subsequently, human agency is rendered invisible. The speed and efficiency of new technologies overshadows more complex issues, politics, and dynamics.

In order to avoid reductionist studies that erase these multifaceted processes, we need theoretical frameworks that reposition as central political action and human agency, as stated by Colombian cultural studies scholar Jesús Martin Barbero in his call for a move from 'the media' to 'the mediations'. According to Martin Barbero:

now more than ever, we need to maintain the epistemological and politically strategic tensions that exist between the historical mediations that establish the scope of influence and meaning that media have on our societies, and the role that the media play today as actual mediators. Without this minimum distance - or negative thinking, as the Frankfurt School would say - critical thought is just impossible. (2006: 280)

Martin Barbero unpacks this notion of mediations, explaining that 'politics are a sort of social fabric where social actors negotiate their identities through interaction' (2006: 284) - a statement that repositions communication as central.

When Martin Barbero first called for a move from the media to mediations in the early 1980s, he was clearly picking a fight with media effects research, which at that time threatened to take over Latin American communication schools. And yet we can find clear parallels in today's research on ICTs and social change. At the time, Martin Barbero questioned the legitimacy of studies that fragment social reality, that disconnect communication and media as if they can be understood in isolation, studies that focused exclusively on the operationalization of information and communication variables. As a response to Martin Barbero's call, scholars in the field of CfSC embraced more complex research approaches that examined media use as traversed by and interlocked with social, economic, and cultural conditions (Rodríguez and Murphy, 1997; Murphy and Rodríguez, 2006). Again, the pronounced visibility of today's ICTs risks leading us into studies that isolate communication and media technologies from history, culture, and politics.

Additionally, we need to add a new threat to these potentially fragmenting approaches, rare at the time Martin Barbero was writing: the availability and easy access to data. It takes a researcher less than 45 minutes to find data demonstrating how the KONY 2012 video went 'viral' immediately after Oprah Winfrey 'tweeted' about it (Rainie et al., 2012). Today's social movements and their uses of ICTs have become a gold mine for researchers looking for big data. A study conducted by the University of Zaragoza's Institute for Biocomputation and Physics of Complex Systems (BIFI) between 25 and 26 April 2011 monitored 70 Twitter hashtags related to the M15 movement in Spain. The study documents the patterns, hubs, and connections of 581,749 Twitter messages and 87,569 users, in an attempt to understand the formation of complex networks (Tarrancón et al., 2011). ${ }^{2}$

As researchers in the area of CfSC, we need to recognize that this type of data is insufficient for answering complex research questions about the cultural negotiations, hegemonic forces, anti-hegemonic resistances, and political economy frameworks that traverse uses of media technologies. We need research that takes seriously the idea that ICTs are used within historical conditions. We need to explore how media technologies are bent in specific ways according to local power dynamics, levels of expertise, 
cultural negotiations, and social interactions. In the following pages, we highlight a few studies that assume the challenge of situating ICTs within complex historical contexts.

Merlyna Lim's research about the uprisings in Tunisia and Egypt reveals the complexities of today's social movements and their use of ICTs. Lim's research on the Egyptian uprising - an event frequently described as a fine example of the so-called 'Revolution 2.0' - finds that what happened in Tahrir Square in 2011 had been in the making for years. If the uprising in Egypt only 'suddenly' made it onto our research radars, it was not because the uprising 'spontaneously' emerged from Facebook and Twitter, but because many of us were not paying attention to the 2003 Tahrir 12 Hours of Protest, the Kefaya movement between 2004 and 2007, or the student protests for judicial independence in 2006, all political actions of dissent spiraling into the 2011 Tahrir Square demonstrations (Lim, 2012: 232-6). Similarly, the failure of international mainstream media to cover collective expressions of dissent in the Middle East contributed to the Arab Spring's broader image as a collection of spontaneous, sudden revolutions (Cottle, 2011).

Lim also demonstrates how social movements of dissent cross-pollinate, learn from each other, and inspire each other in their uses of ICTs. In Egypt, Lim identifies how the Tahrir uprising adopted the use of Twitter from the April 6th Youth Movement, despite the latter's failure to generate mass protests (Lim, 2012: 239-41). More broadly, many of the representational tactics employed during the start of the Arab Spring can be traced to a postcolonial aesthetics of resistance that circulated within the eastern Mediterranean and North Africa for decades by way of Arabic cinema, journalism, and literature. This example is far from being exceptional. The Indymedia network, often presented as a spontaneous initiative of Global Justice Movement activists during the anti-WTO conference in Seattle in 1999, was actually the product of years of maturation within transnational networks of activists, especially in the aftermath of the Zapatista rebellion in Chiapas, Mexico, in 1994 (Ferron, 2012a: 402-36; Wolfson, 2012). In other words, research in the field of CfSC needs to keep track of and monitor how alternative, community, radical, and citizens' media activists and practitioners share know-how, redefine technologies' potential, and articulate their own goals for media technologies.

Lim's research on Egypt emphasizes the complexity of communication processes in situations of dissent and social mobilization. Communication is required for social movements to gain momentum and galvanize collective political action, but this generally implies a multiplicity of forms of communication, from the performative communication of bodies in the street to the disembodied informational act of texting a meeting time and place; according to Tufekci and Wilson (2012: 370), 48.4\% of participants first heard about the Tahrir Square demonstrations through face-to-face communication, 28.3\% through Facebook, and 13.1\% via telephone. In Egypt, Lim identifies taxi drivers and food vendors as key communicators, and coffee shops, mosques, and soccer fields as crucial spaces for information dissemination (Lim, 2012: 242-3). Similarly, Gerbaudo (2012) identifies how anti-globalization activists played key roles during the Indignados movement in Spain; so did anarchists during the Occupy movement in the United States (Gerbaudo 2012: 143). Based on ethnographic data from various case studies, Gerbaudo (2012) insists on the need to understand how media practices happen in interaction with 
specific localities; his study centers on how interactions between movements and media choreograph specific forms of mobilization.

Finally, Lim's research shatters the flattening effect of Facebook and Twitter, where every communicator becomes a data point. In the Tahrir demonstrations many different social movements joined forces, playing key but differentiated roles; the Muslim Brotherhood knew how to handle the logistics of feeding so many people and Cairo's soccer fans employed their street-battle know-how (Lim, 2012: 243).

Research on social movements and media use that takes historical context seriously demonstrates that media repertoires do not happen in a social vacuum. A recent study that compares the media repertoires of the Zapatista movement with those of the AntiOccupation Movement in Israel/Palestine (Ferron, 2012a) shows that social movements' uses of media technologies are mediated by a complex mesh of factors that include the internationalization of the political capital of activist networks, interaction between alternative and mainstream media, as well as specific individual and organizational trajectories of the so-called 'mediactivists'. In 1994 Subcomandante Marcos, the iconic leader of the Zapatista movement, didn't even have access to a computer; the houses where Marcos wrote his famous communiqués didn't have access to the internet (Ferron, 2012a: 403). Based on fieldwork in Chiapas and Mexico City, methodical historical research, and hundreds of hours of interviews, Benjamin Ferron's study reveals how many different individuals and collectives, with their own biographies, know-how, and political passions, shaped the movement's media use. For example, Elliot Young, a graduate student doing fieldwork in Mexico for his dissertation in history, became key in translating and posting information about the Zapatistas. At the time, Young used precarious e-bulletin boards to transmit text and sold VHS tapes for less than a dollar to distribute video material (Ferron, 2012a: 407-16). Young's access to a computer and a video camera, and his knowledge of media were crucial to that specific moment. Still, the role played by activists is not enough to explain the remarkable case of Zapatista media use.

Another key factor was the interaction between the mainstream media and the Zapatista leadership. According to Ferron's comparison, while the Anti-Occupation movement in Palestine benefited from the variable but constant attention of the mainstream media to the Israeli-Palestinian conflict, the Zapatistas were dropped from national and international media soon after the first wave of drama around Marcos from 1994 to 2001. As a result, the Anti-Occupation movement is generally trying to 'correct' the mainstream media, while Marcos and the Zapatistas almost gave up on the mainstream media and decided to develop their own alternative media system when the newsworthiness of the Chiapas conflict declined. In these two cases, looking at how social movements, mainstream media, and dissent media interact is key to understanding the differentiated paths of Zapatista media and Anti-Occupation media.

Moreover, Ferron shows that the catch-all expression 'alternative media' actually refers to many different concrete social spaces of cooperation/rivalry relationships. Indeed, the production and reproduction of these media generally depend on weak economic and organizational resources. This situation generates constant tension within and between the network of media activists. The study of the rupture between the 'Free Radio' and the 'Community Radio' network that emerged in Mexico City after the huge 
student strike of the National Autonomous University in 1999-2000 clearly illustrates the structuring dimension of these internal divisions between a radical and a citizens' pole, particularly when relationships between 'alternative media' and the state and the market are at stake (Ferron, 2012b).

Kristin Shamas's (2011) research on ICT use in Lebanon highlights the importance of historical context in studies on social movement media. Using a multi-pronged methodological approach, Shamas explores how media shape and are shaped by subjectivities, and how this interaction is itself determined by complex historical contexts. During the 2006 war between Israel and Hizbollah, a contingent of Lebanese-descended bloggers emerged as a powerful form of citizens' media that sought to counter the propagandistic, dispassionate, and misinforming coverage provided by international mainstream media. Shamas's study takes seriously the idea that media use happens in specific and multifaceted historical conditions that sometimes require longitudinal studies. Working to understand the historical conditions that gave rise to the prolific outpouring by Lebanese bloggers in 2006, the study finds key answers in Lebanese literature produced during and after the 1974-90 Lebanese Civil War. A detailed analysis of how these literary texts discuss communication technologies reveals ways in which local and global media were inadequate to meet the information and communication needs of the people in Lebanon during decades of armed conflict. Lebanese literature articulates how national media were unable to go beyond partisan frameworks that incited more violence; how local and international news stories de-humanized 'the other'; how the lived experience of war was flattened by 'objective' practices within global journalism. For example, in the autobiographical Beirut Fragments: A War Memoir, the narrator compares the lived experience of violence with past accounts of war:

On the way out I pick up a piece of shrapnel from the rubble. Shrapnel. So this is shrapnel, I think. I never took it seriously before. Somehow when I had heard someone had died of shrapnel wounds, it hadn't sounded quite as serious as dying from a bullet or in a fire. But this jagged, heavy, twisted, hot piece of iron - this is shrapnel. Shrapnel is serious. (in Shamas, 2011: 145)

In Jad El-Hage's The Myrtle Tree, the narrator critiques how local media has covered the war:

People took their radios with them everywhere. Each had his favourite station. Radio Volcano, for instance, promised nothing less than the end of the world. Its airwaves were served by speakers straight out of Armageddon. They vowed to kill everyone including babies and the unborn. [...] But the weirdest of all was Radio Anarchy. This one transmitted a freakish mishmash of sound effects: children crying, explosions, ambulance sirens, parodies of songs, recording from live battles, street commotion, soundtracks from hospital operating theatres. (in Shamas, 2011: 155)

Lebanese literature, particularly the civil war novel, became a cultural space used by the Lebanese to articulate alternative visions of media and communication (Shamas, 2011). For example: Samuel Hazo's novel Stills depicts a war photographer trying to 
capture the complexities of the lived experience of war (Shamas, 2011: 161). The Lebanese civil war novel also highlights the value of local, informal, sometimes hidden information and communication networks. In The School of War, men gather at the barbershop every morning to piece together fragments of information (Shamas, 2011:163). In De Niro's Game 'the women from the building met every morning over coffee to exchange news about the prices and availability of food and any other information they had' (Shamas, 2011: 163-4). The novels highlight people's agency as they develop their own information and communication systems and networks, countering their frustration with mainstream media. Years before the emergence of the Lebanese blogosphere, these novels signaled the failure of single-voice media narratives for capturing the experience of war, and repositioned as central lived experience - as opposed to detached 'objective journalistic coverage' - both key characteristics of Lebanese blogging during the 2006 war. Literature was the site of an intense and polyvocal public conversation about, first, the inability of current media structures to meet the information and communication needs of the Lebanese people and, second, the need to "design alternative media systems to overcome the "betrayal" of traditional news media' (Shamas, 2011). This research demonstrates how, in Lebanon, the social conditions that triggered the 2006 generation of bloggers were in the making for decades. In a similar vein, Sreberny and Khiaban suggest that Iran's enormous blogosphere can only be explained by looking at complex historical conditions, including 'the legacy of a revolutionary political culture, the perception and experience of repression by citizens, culturally preferred modes of expressivity as well as the meaning and experience of the Iranian diaspora' (2011: xi).

The type of research undertaken by Lim, Ferron, and Shamas addresses Martin Barbero's call to apply 'our continuous effort to disentangle the increasingly complex fabric of mediations that articulates the relations between communication, culture and politics' (2006: 281). By taking historical context seriously, these research studies overcome several challenges: first, assuming that communication phenomena are tightly woven with other historical processes, dynamics, and conditions, they avoid the deterritorialization of communication research; second, they maintain the epistemological tension between the media and mediations; and, third, they break away from disciplinary isolation and explore other fields, such as literary studies, social movements studies, and the sociology of journalism to find answers about media use.

\section{Risk two: separating media and ICTs from their political economy frameworks}

In Colombia, the term 'minute' has become a common trope in social life. Walking down the street, the word 'minutes' appears on all types of signs, from the hand-written cardboard signs of street vendors to sophisticated, professionally printed banners. In Colombia, cellular telephony regulation mandates that the caller, rather than the receiver of the call, pays for the call. People use their own cell phones predominantly to receive calls, and then buy cell phone minutes to make calls. In the digital divide, who are these call-receiving Colombians? Are they cell phone haves? Or have-nots? This is a key 
question if we are to understand how Colombians are using cell phones - the political economy of cellular telephony in Colombia.

Jack Qiu (2009) reminds us that ICTs do not happen in a contextual vacuum. They have a material positionality in the political economy of information and communication. Qiu's superb analysis of the information 'have-less' in urban China questions the use of short-cut terms such as 'the digital divide' (Qiu, 2009). Qiu reveals how the idea of the 'digital divide' creates blinders that obscure complexities in how ICTs are used in specific contexts, as their use is mediated by class, mobility, age, and closeness or distance from the production of ICTs. Qiu takes on the challenge of investigating what exactly is happening in working-class communities in urban China and how they use ICTs, like internet cafés and wireless phones, including how specific groups such as migrants or senior citizens use these technologies to meet their information and communication needs.

We need to always remember that all uses of media are framed by the political economies of ICTs. While we can applaud their potential for social change, we can never forget how ICTs are shaped and molded by regulatory regimes, international trade, corporate greed, and intrusive surveillance practices on the parts of both financial and political powers. As Sasha Costanza-Chock says, 'in business-speak, "User Generated Content" means free cultural product for monetization and cross-licensing, "participation" means free user data to mine and sell to advertisers, and all user activity is subject to surveillance and censorship' (2008: 857). Or, in harsher terms, Web 2.0 can be seen as 'a venture capitalist paradise where investors pocket the value produced by unpaid users, ride on the technical innovations of the free software movement, and kill off the decentralizing potential of peer-to-peer production' (cited by CostanzaChock, 2008: 857). If Web 2.0 has become a corporate paradise for free technical innovation and user-generated content, the next generation of social media platforms - known as Web 3.0 - privileges technologies that connect vast networks of users and organize data, maximizing consumers' profiles, matching profiles with corporate advertising, and refining surveillance of online identities (Barassi and Treré, 2012). As Barassi and Treré assert, 'these applications propose to manage, organize and create meaning from user-generated data in such a way that it maximizes the tracing of digital identities (Harris, 2008; Watson, 2009) and behavioural advertising (Barassi and Treré, 2012; Tasner, 2010).

Contagious waves of enthusiasm over Web 2.0 and 3.0 spill over from corporate spheres into social movements and academic circles. 'Old' media technologies such as radio and print media begin to sound 'primitive'. And yet, when examined in their degree of 'separability' and autonomy from their corporate originators, old technologies fare better. When used by social movements or grassroots organizations, audio cassettes, faxes, or murals can be entirely separated from corporate interests, adapted and reinvented to meet local information and communication needs (Downing, 2010; SrebernyMohammadi and Mohammadi, 1994). Even a radio station powered by solar energy or batteries allows for more autonomy from corporate interests and state surveillance than Facebook, YouTube, or Twitter. Still, the dazzling speed and immediacy of social media platforms tend to overshadow academic interest in 'old' ICTs. 


\section{Risk three: using simplistic definitions of communication}

In contexts of social dissent and social change, collective uses of media technologies include a complex mesh of different modes of communication. Wanting to explore how people living in regions of armed conflict use media technologies, Clemencia Rodríguez developed a research study on citizens' media among unarmed communities living in war regions in Colombia (Rodríguez, 2011). Originally, the idea was to focus on how media technologies are used for purposes of mobilization against war or for alternative coverage of war. However, during fieldwork, these notions of communication understood as simply 'information' or 'reporting' became too narrow and myopic and gave way to a much more complex understanding of communication.

The recent excitement around Facebook and Twitter emphasizes the use of ICTs for dissemination of information among networks of individuals. In contrast, Colombian community communicators use media technologies to 'trigger' different types of communication processes - they intervene to repopulate the public sphere, to activate interaction between local government officials and their constituencies, or to trigger performative communication happenings.

Local public spheres are among the first casualties when unarmed communities are caught in the fighting of warring groups. People witness their streets and plazas being invaded by heavily armed groups. Sandbag barricades are erected to protect local police stations or government buildings. In this kind of war, local geographies become sites of surveillance, sometimes through informants recruited by armed groups from the local population. When public places are permeated by suspicion, people desert them and retreat to their private spaces, and the social fabric starts to erode. To counter this impact of war on the everyday life of its community, Radio Andaquí, a community radio station in southern Colombia, designed a Christmas decorating contest. To purposely encourage neighbors to interact and repopulate their streets, Radio Andaquí defined contestants as blocks, not individual households. As a result, people on the same block began interacting, fetching tools, painting and decorating together. The station then used its radiocycle, a mobile unit mounted on a tandem bicycle, to transmit from a different block every night. Little by little, neighbors began coming and going from one block to another, comparing decorating strategies. Radio Andaquí knows that each of those conversations is a thread in the social fabric that sustains the community and keeps the terror of war at bay. In this case, the community medium designed a communication intervention intended to repopulate a deserted public sphere. Even the prize, a block party, is designed to trigger and cultivate communication and interaction, not between the medium and its audience, but among community members (Rodríguez, 2011).

In this case, the community communicators behind the medium carefully designed ways to use media technologies to 'trigger' specific dynamics among the community. The talent for designing these communication happenings was developed through years of experimenting with technology, sharing know-how with other community communicators, and applying immense doses of creativity. These Colombian community communicators have a profound understanding of the communication and information needs of their community in times of war. Information and communication needs are not defined solely in terms of information dissemination or news. 
Instead, these communicators have learned to see the social fabric of a community as a mesh of communication dynamics that shape people's sense of identity, their sense of belonging and agency, and togetherness - all necessary ingredients for collective action (Rodríguez, 2011).

Colombian community communicators operate as relentless ethnographers, continuously exploring every nook and cranny in their community to detect communication and information needs and to figure out ways to use media technologies to meet those needs. They know how changing historical conditions impact on communication and information processes; they detect the opening of new communication spaces even while others may be closing; they understand how social, political, and economic dynamics impact on communication processes in the community.

Rodríguez's research documents numerous other instances in which community communicators, like Radio Andaquí and their Christmas decorating contest, designed community communication interventions - similar to media happenings - tailored to meet local communication needs. In Colombian regions of armed conflict, community media are used to move already existing communication processes from isolated margins to central positions. For example, sometimes in moments of collective terror, when a community is under siege or attack by armed groups, subtle, frail moments of resistance emerge in unexpected places. Detecting these emerging dynamics, these communicators design spontaneous media uses that strengthen precarious expressions of collective agency. Media are used to help move the community from being mere victims of armed groups, paralyzed and silenced, toward a collective of active agents with a voice (Rodríguez, 2011).

In other cases, media are used to open communication spaces in which men, women, and children find ways to articulate the lived experiences of human rights violations and other modes of victimization at the hands of armed groups in the form of camouflaged messages that won't alert armed groups (Nordstrom, 2004; Ramírez, 2001). Frequently, community media carefully and safely move these messages from private to public spheres, allowing feelings of shared experience to grow.

Similarly, community communicators use media to improve governance, monitor local governments to increase transparency, monitor local elections, de-escalate potential violent conflicts within the community, strengthen peace-building community initiatives, re-build trust in post-conflict situations, counter the disintegration of life-worlds caused by war, re-signify social and cultural spaces hijacked by armed groups, strengthen dimensions of life not permeated by war, reconnect families and communities separated by war, negotiate and mediate with armed groups, assist refugee families, and coordinate food distribution and other logistics (Rodríguez, 2011). As they design media uses to trigger or cultivate specific processes, community communicators understand that they need to use the full battery of forms of communication: persuasive communication along with diffusion of information, participatory communication, communication that empowers, communication that mobilizes, and citizens' journalism.

Most interesting, however, is their understanding of the performative potential of communication. Colombian community communicators have learned that media technologies can be used 'to make things happen' within a community. Media are used not just to inform, transmit messages, or empower. They literally make things happen, 
moving into the realm of performative communication. For example, instead of sending messages describing non-violence or trying to persuade people to live non-violently in a war-torn community, a radio station triggers a process of non-violent conflict resolution in the community. The medium allows people to experience non-violent ways to manage conflict; the medium subjects people to what non-violent conflict resolution feels like (Rodríguez, 2011).

But for community communicators to activate performative media, the technologies need to be malleable and flexible. As with Radio Andaquí's radiocycle, community communicators need to be able to re-invent, bend, hybridize media technologies. But what about the plasticity of social media platforms? Is it more or less difficult to bend these technologies? Clearly, grassroots organizations and leaders are learning how to bend social media platforms. Progressive software designers are developing applications specifically designed to meet the communication needs and demands of social movements; to facilitate digital story-telling among communities with limited access to technology, a universitybased team working with a group of low-wage immigrant workers co-designed an application that allows Latina/o immigrants to upload photos and interviews using basic cellular phones (The VozMob Project, 2011). Recently YouTube released a new tool that allows users to blur the faces of demonstrators in YouTube videos in order to protect anonymity and to bypass state or police surveillance (Gregory, 2012). These new technologies, however, are not easily cut off from the for-profit intentions of their originators, again emphasizing the importance of political economy discussed in the previous section.

\section{Fourth risk: losing track of the field and re-inventing the wheel}

As scholars in the area of CfSC, we need to maintain historical, longitudinal perspectives on how social movements have used and are using ICTs; we need theoretical and methodological approaches that recognize the complex mesh of factors that shape the potential of media technologies in contexts of dissent and/or social change. Among these factors, speed, immediacy, and the potential to reach massive audiences are important, but so are issues of autonomy from corporate and political powers, surveillance and anonymity, cultural malleability, and technological plasticity. New studies on ICTs and social movements need to be strongly grounded in this field of research that has flourished since the 1960s. Otherwise, we run the risk of fragmenting findings and simply re-inventing the wheel if we lose track of the field of research in the area of CfSC.

In an article in the Journal of Women's Health, Carolyn Wang (1999), a public health scholar working with women's health issues in rural China, analyzes an allegedly new participatory communication strategy called 'Photovoice', which entails women using photo cameras to document their lives and health (1999). Wang explains:

People merely creating images is not the key to Photovoice, however. The process also requires that people define those images. Photovoice entails people discussing images that they have produced, and by doing so, they give meaning to, or interpret, their images. By women telling their and their communities' stories, we might better understand the context that women confer their lives and health conditions. (1999: 186) 
Apart from a single nod to Paulo Freire, the author makes no reference to nor builds upon any of the numerous discussions about media making and empowerment that pepper the field of participatory video. Not one single reference to the late 1960s Fogo Process (Quarry, 1994; Waugh et al., 2010), or Pilar Riaño’s (1994) well-known book on women and grassroots communication, or Maria Protz's (1994) work with video and women in India, or Rosa Maria Alfaro's work with video and women in inner city Lima, Peru, or Pat Aufderheide's (1995) work with the 'Video in the Villages' project in Brazil, just to name a few.

This type of scenario, in which an anthropologist or public health researcher stumbles upon community media and 'discovers' it as a 'new' area of research is not exceptional. We are seeing an increasing number of submissions to communication journals in which authors investigate community, participatory media, or radical, militant, social movements' media as if they were the first ones to write about the subject. Authors cite anthropological or public health sources but do not link to the field of social movement media, participatory media, or community/alternative/citizens' media. While not very old, this area of research has accumulated a significant body of knowledge since the 1980s. As a field of study, research on social movement media, participatory media, community/ alternative/citizens' media has clear boundaries, a canon, a set of classics, several generations of experts, ongoing debates, major theoretical and methodological contributions (especially in areas such as agency and voice, interconnections between communication and power, communication and culture as political actions), and key historical moments (the Iranian revolution, the Nicaraguan revolution, Zapatista uses of media technologies, Indymedia, to name just a few of the most salient examples). Within the discipline of communication, community/alternative/citizens' media is arguably the most internationalized area of research. Losing track of the richness of the field, and conducting research on media, social movements, and social change as if the field of CfSC did not exist, puts at risk significant opportunities to build upon already existing knowledge gleaned from a multitude of locations, contexts, and conversations.

\section{Conclusion}

During the 1980s and 1990s, community/alternative/citizens' media research had an extremely low population density; at the time, researching alternative media was first, obscure, and, second, looked down upon as completely useless and anachronistic - after all, the Berlin Wall had fallen down, and academic conference halls brimmed with enthusiasm for free markets and mainstream media. Today we experience a very different type of scenario, where discussions around social movements and alternative uses of ICTs have become so trendy that we see them everywhere, including among mainstream media and corporate voices boasting about their role in revolutionary contexts. To adequately understand the rich historical contexts, political economy frameworks, and complex modes of communication involved in these media happenings will require a commitment to engaging existing research and pushing it in new directions.

It has been a long journey from the time of tin miners' radio stations in Bolivia and uses of video for empowerment on Fogo Island; and yet here we are today, after having witnessed and studied the Iranian revolution, the Zapatistas, Indymedia, the World Social 
Forums, the Arab Spring, the 'Indignados' movement, and the Occupy movement. As researchers in the field of community/alternative/citizens' media, our challenge is to help facilitate an organized interchange of research, methodologies, and ideas. We must continue positioning the field, with its rich history, previous and new debates, and major contributions to the discipline. Initiatives such as John Downing's Encyclopedia of Social Movement Media (2010), or Alfonso Gumucio Dagron's and Thomas Tufte's Communication for Social Change Anthology (2006) have made key contributions to positioning the field. We all need to continue this trend.

\section{Funding}

This research received no specific grant from any funding agency in the public, commercial, or not-for-profit sectors.

\section{Notes}

1. Benjamin Ferron (2012a) compiled numerous terms, including: alternative, radical, citizens', marginal, participatory, counter-information, parallel, community, underground, popular, libres, dissident, resistance, pirate, clandestine, independent, new, young, micro - showing that the struggles for the definition of these media are inseparably struggles for legitimizing or delegitimizing them.

2. See: www.youtube.com/watch? $\mathrm{v}=\mathrm{H} 5 \mathrm{w} 4 \mathrm{amBIHj} 4 \&$ feature=youtu.be

\section{References}

Ali AH (2011) The power of social media in developing nations: new tools for closing the global digital divide and beyond. Harvard Human Rights Journal 24: 185-219.

Aufderheide P with Carelli V (1995) The 'Video in the Villages' project: videomaking with and by Brazilian Indians. Visual Anthropology Review 11(2): 83-93.

Axford B (2011) Talk about a revolution: social media and the MENA uprisings. Globalizations 8(5): 681-686.

Barassi V and Treré E (2012) Does Web 3.0 come after Web 2.0? Deconstructing theoretical assumptions through practice. New Media \& Society, published online 14 June.

Bennett WL and Segerberg A (2011) Digital media and the personalization of collective action. Information, Communication \& Society 14(6): 770-799.

Boddy W (1990) Alternative television in the United States. Screen 31(1): 91-101.

Boyle D (1997) Subject to Change: Guerrilla Television Revisited. New York: Oxford University Press.

Chadaigne PJ (2002) La Communication alternative: la presse parallèle en France des années 60 à la fin des années 90 . Unpublished doctoral thesis, Université Paris II.

Chipembere LJ (2011) Music and social protest (Malawi). In: Downing JDH (ed.) Encyclopedia of Social Movement Media. Thousand Oaks, CA: Sage, pp. 347-351.

Christensen C (2011) Twitter revolutions? Addressing social media and dissent. Communication Review 14(3): 155-157.

Cohen R (2011) Facebook and Arab dignity. The New York Times, 24 January. Available at: www. nytimes.com/2011/01/25/opinion/25iht-edcohen25.html (accessed 8 December 2013).

Costanza-Chock S (2008) The immigrant rights movement on the net: between 'Web 2.0' and Comunicación Popular. American Quarterly 60(3): 851-864.

Cottle S (2011) Media and the Arab uprisings of 2011: research notes. Journalism 12: 647-659. 
Cottle S and Lester L (2011) Transnational Protests and the Media. New York: Peter Lang.

Drijvers J (1992) Community broadcasting: a manifesto for the media policy of small European countries. Media, Culture \& Society 14(2): 193-201.

Downing JDH (1991) Community access television: past, present and future. Community Television Review 14(3): 6-8.

Downing JDH (2010) Encyclopedia of Social Movement Media. Thousand Oaks, CA: Sage.

Ferron B (2012a) Les Répertoires médiatiques des mobilisations altermondialistes. Contribution à une analyse de la société transnationale. Unpublished doctoral thesis, Université de Rennes, France. Available at: http://tel.archives-ouvertes.fr/docs/00/73/18/09/PDF/THESE_ BENJAMIN_FERRON.pdf (accessed January 2014).

Ferron B (2012b) Giving voice to the voiceless or giving peace to the establishment? The ambivalent institutionalization of alternative minority media in Mexico and Israel. In: Rigoni I and Saïta E (eds) Minority Media in a Globalized Public Space. New York: Palgrave, pp. $135-152$.

Fox E and Schmucler H (1982) Comunicación y Democracia en América Latina. Lima, Peru: DESCO.

Gerbaudo P (2012) Tweets and the Streets: Social Media and Contemporary Activism. London: Pluto Press.

Gladwell M (2010) Small change: why the revolution will not be tweeted. The New Yorker. Available at: www.newyorker.com/reporting/2010/10/04/101004fa_fact_gladwell (accessed 8 December 2013).

Gregory S (2012) Visual anonymity and YouTube's new burring tool. Blog. Available at: http:// blog.witness.org/2012/07/visual-anonymity-and-youtubes-new-blurring-tool/ (accessed 8 December 2013).

Gumucio Dagron's A and Tufte T (eds) (2006a) Communication for Social Change Anthology: Historical and Contemporary Texts. New York: Communication for Social Change Consortium.

Gumucio Dagron A and Tufte T (2006b) Roots and Relevance. Introduction to the CfSC Anthology. In Gumucio Dagron A and Tufte T (eds) Communication for Social Change Anthology: Historical and Contemporary Texts. New York: Communication for Social Change Consortium, pp. xiv-xxxvi.

Hagerstrand T (1986) Decentralization and radio broadcasting: on the 'possibility space' of a communication technology. European Journal of Communication 1(1): 7-26.

Halleck D (2001) Hand-held Visions: The Uses of Community Media. New York: Fordham University Press.

Harlow S (2012) Social media and social movements: Facebook and an online Guatemalan justice movement that moved offline. New Media \& Society 14(2): 225-243.

Howard PN and Hussain M (2011) The role of digital media. Journal of Democracy 22(3): 35-48.

Huesca R (1996) Participation for development in radio: an ethnography of the Reporteros Populares of Bolivia. Gazette 57(1): 29-52.

Jankowski N, Prehn O and Stappers J (eds) (1992) The People's Voice: Local Radio and Television in Europe. London: John Libbey.

Juris JS (2012) Reflections on Occupy Everywhere: social media, public space, and emerging logics of aggregation. American Ethnologist 39(2): 259-279.

Lewes J (2000) The underground press in America (1964-1968): outlining an alternative, the envisioning of an underground. Journal of Communication Inquiry 24(4): 379-400.

Lewis PM (ed.) (1984) Media for People in Cities: A Study of Community Media in the Urban Context. Paris: UNESCO. 
Lim M (2012) Clicks cabs, coffee houses: social media and the oppositional movements in Egypt (2004-2011). Journal of Communication 62: 231-248.

Kidd D and Rodríguez C (2009) Introduction. In: Rodríguez C, Kidd D and Stein L (eds) Making Our Media: Global Initiatives Toward a Democratic Public Sphere. Cresskill, NJ: Hampton Press, pp. $1-22$.

Khondker HH (2011) Role of the new media in the Arab Spring. Globalizations 8(5): 675-679.

Martin Barbero J (2006) A Latin American perspective on communication/cultural mediation. Global Media and Communication 2(3): 279-297.

Michaels E (1994) Bad Aboriginal Art: Tradition, Media, and Technological Horizons. Minneapolis: University of Minnesota Press.

Murphy PD and Rodríguez C (2006) Introduction: between Macondo and McWorld: communication and culture studies in Latin America. Global Media and Communication 2(3): 267-277.

Nordstrom C (2004) Shadows of War: Violence, Power, and International Profiteering in the Twenty-first Century. Berkeley: University of California Press.

Nyamnjoh FB (2006) Communication research and sustainable development in Africa: the need for a domesticated perspective. In: Gumucio-Dagron A and Tufte T (eds) Communication for Social Change Anthology: Historical and Contemporary Texts. New York: Communication For Social Change Consortium, pp. 597-609.

Oduro-Frimpong J (2011) Music and dissent (Ghana and Nigeria). In: Downing JHD (ed.) Encyclopedia of Social Movement Media. Thousand Oaks, CA: Sage, pp. 346-347.

Pfeifle M (2009) A Nobel Peace prize for Twitter? Christian Science Monitor, 6 July. Available at: www.csmonitor.com/Commentary/Opinion/2009/0706/p09s02-coop.html (accessed 8 December 2013).

Protz M (1994) Understanding women's grassroots experiences in producing and manipulating media. In: Riaño-Alcalea P (ed.) Women in Grassroots Communication: Furthering Social Change. Thousand Oaks, CA: Sage, pp. 102-120.

Qiu JL (2009) Working-class Network Society: Communication Technology and the Information Have-less in Urban China. Cambridge, MA: MIT Press.

Quarry W (1994) The Fogo Process: An Experiment in Participatory Communication. Unpublished thesis, University of Guelph.

Rainie L, Hitlin P, Jurkowitz M, Dimoch M and Neidorf S (2012) The viral KONY 2012 video. Pew Internet. Available at: www.pewinternet.org/Reports/2012/Kony-2012-Video.aspx (accessed 11 August 2013).

Ramírez MC (2001) Entre el Estado y la Guerrilla: Identidad y Ciudadanía en el Movimiento de los Campesinos Cocaleros del Putumayo. Bogotá: ICAHN.

Reyes Matta F (1983) Comunicación Alternativa y Búsquedas Democráticas. México: Fundación Friedrich Ebert and ILET (Instituto Latinoamericano de Estudios Transnacionales).

Riaño Alcalá P (ed.) (1994) Women in Grassroots Communication: Furthering Social Change. Thousand Oaks, CA: Sage.

Rodríguez C (2011) Citizens' Media Against Armed Conflict: Disrupting Violence in Colombia. Minneapolis: University of Minnesota Press.

Rodríguez C (2001) Fissures in the Mediascape: An International Study of Citizens' Media. Cresskill, NJ: Hampton Press.

Rodríguez C and Murphy P (1997) The study of communication and culture in Latin America: from laggards and the oppressed to resistance and hybrid cultures. Journal of International Communication 4(2): 24-45.

Roncagliolo R (1991) The growth of the audio-visual imagescape in Latin America. In: Thede N and Ambrosi A (eds) Video the Changing World. Montreal: Black Rose Books, pp. 22-30. 
Roth L and Guthrie Valaskakis G (1989) Aboriginal broadcasting in Canada: a case study in democratization. In: Raboy M and Bruck P (eds) Communicating For and Against Democracy. Montreal: Black Rose Books, pp. 221-234.

Shamas K (2011) Lebanese Subjectivities and Media Use: Post/Global Contexts. Unpublished doctoral thesis, University of Oklahoma.

Simpson Grinberg M (ed.) (1981) Comunicación Alternativa y Cambio Social: América Latina. Mexico City: Universidad Nacional Autónoma de México.

Spitulnik D (2003) Alternative small media and communicative spaces. In: Hyden G, Leslie M and Ogundimu FF (eds) Media and Democracy in Africa. New Brunswick, NJ: Transaction Publishers, pp. 177-205.

Sreberny A and Khiaban K (2011) Blogistan: The Internet and Politics in Iran. New York: I.B. Tauris.

Sreberny-Mohammadi A and Mohammadi A (1994) Small Media, Big Revolution: Communication, Culture, and the Iranian Revolution. Minneapolis: University of Minnesota Press.

Tarrancón A, Borge-Holthoefer J and Moreno Y (2011) Estudio Sobre el 15M en las Redes Sociales. University of Zaragoza, Institute for Biocomputation and Physics of Complex Systems (BIFI) and CIERZO Development. Available at: 15m.bifi.es/index.php (accessed 11 August 2013).

The VozMob Project (2011) Mobile voices: projecting the voices of immigrant workers by appropriating mobile phones for popular education. In: Napoli P and Aslama M (eds) Communication Research in Action: Scholar-Activist Collaborations Toward a Democratic Public Sphere. Bronx, NY: Fordham University Press pp. 177-196.

Thede N and Ambrosi A (1991) Video the Changing World. Montréal: Black Rose Books.

Trejo R (1980) La Prensa Marginal. México, DF: Ediciones El Caballito.

Tufekci Z and Wilson C (2012) Social media and the decision to participate in political protest: observations from Tahrir Square. Journal of Communication 62: 363-379.

Ugboajah FO (2006) Oramedia in Africa. In: Gumucio-Dagron A and Tufte T (eds) Communication for Social Change Anthology: Historical and Contemporary Texts. New York: Communication for Social Change Consortium, pp. 293-301.

Waisbord S (2001) Family tree of theories, methodologies and strategies in development communication: convergences and differences. Paper prepared for the Communication for Social Change Consortium. Available at http://www.communicationforsocialchange.org/pdf/familytree.pdf

Wang CC (1999) Photovoice: a participatory action research strategy applied to women's health. Journal of Women's Health 8(2):185-192.

Waugh T, Brendan Baker M and Winton E (eds) (2010) Challenge for Change: Activist Documentary at the National Film Board of Canada. Montreal-Kingston: McGill-Queens University Press.

Wolfson T (2012) From the Zapatistas to Indymedia. dialectics and orthodoxy in contemporary social movements. Communication, Culture and Critique 5: 149-170.

Zhuo X, Wellman B and Yu J (2011) Egypt: the first internet revolt? Peace Magazine 27(3): 6. 